\title{
組織ノぐりこりーぜニ 及ボス溫度ノ影譍
}

京都帝國大學醫學微生物學教室（主任 木灲教授）

平 井禎 三

本研究ニ對シテハ帝國學士院ノ補助 7 得タリ記シテ以ラ謝意ヨ表ス。

\section{【内容 抄 錄】}

へもぐりこりーぜト温度卜密接ナル關係八既二先賢つ認ムル所ナリ，余入本篇二於テ組織ぐり こりーでト溫度卜ノ關係キ探究七ント欲シ，組織胎外培養法キ應用シテ種々ナル温度ニ於ケル培 養組織ノ發有並ビ二糖消費卜ノ關係斗觀察シ，次ノ如キ結果キ得タリ。節千組織ぐりこりーゼノ

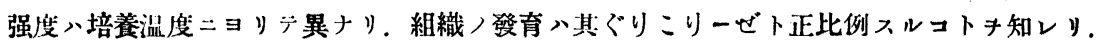

目

粕 言

第 1 章 實驗方法

第 1 節 培養方法並二供試材料

第 2 節 培養組䇝發有圈测定方法

第 3 節 培養温度

第 4 節 含糖量測定法

\section{次}

第 2 章 賽驗成績

第 1 節 堟備試驗

第 2 節 本 試 驗

第 3 章 總括

第 4 章 結 論

\section{橉言}

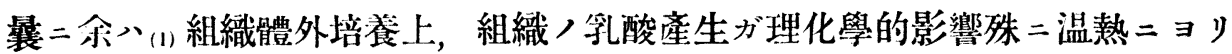
ラ差異アルコトヨ報告シタリ.

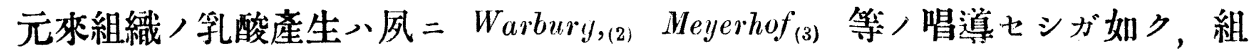
織ノぐこりーぜニョリテ惹起セラレ, 兩者、互二密接ナル關係ニアルモノナ レバ，典ニ余ガ行ヒタル實驗ノ如ク猞酸生成ガ温熱作用ニョリテ影響セラルモ ノナルガ故二，其乳酸ノ生成原ナルぐりこり一せモ亦温熱作用卜何等カ，關係 ニアルモノナラント考フルハ亦目ナルべシ.

於茲余ハ以上ノ事項 $\exists$ 確カメント欲シ本實驗二着手セリ.

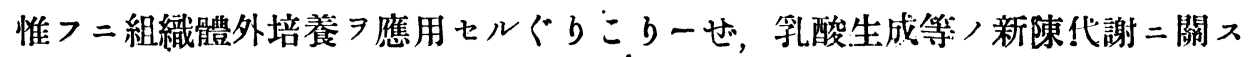
ル業績、寒々タルモノナリシガ, 最近 2,3 ，學究者ニヨリテ樭タ興味アル新知 


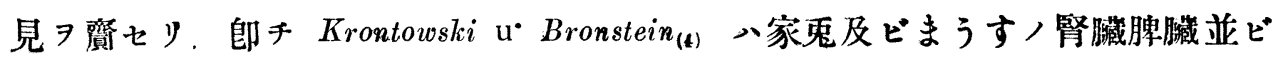
二癌培養特二於ケル糖量, 消長 9 追究シ, 稫光氏 ${ }_{(5)}$ 八亦家䳕胎兒心臟, 脾獩

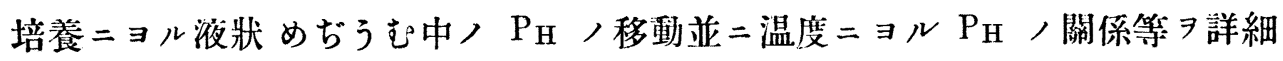

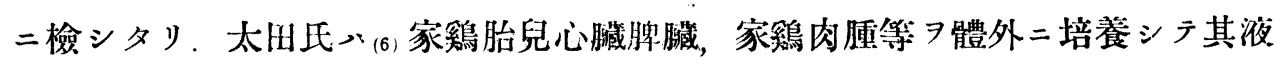
狀めぢうむ中, 乳酸量並二糖量八關係 $\ni$ 檢索シ, Demuth u. Meier ${ }_{(7)}$ 八乳酸生 成 $\ni, R$ offo $o_{(8)}$ 八解糖作用二就テ太田氏同樣，成績 $\ni$ 公二セリ.

斯クノ如ク上記諸氏ノ究ムル所其研究方法稍々異ナルコトアリト踓モ，其， 示ス所ホボ一致スルタ見タリ.

師天組織, 發有進ムト共二培莨液中, 糖量ハ消費セラレテ减少シ, 一方酸形 成 織ト一定ノ關係 7 保ッコト明カトナレリ.

斯クノ如クぐりこり一ぜ組織ノ發育ニ八必然的要約ナレドモ, コノぐここ りーせ济果シテ Glycoiytisches Ferment ニョリテ招來セラルルモノナリヤ, 將亦物理化學的機轉ニョツテ起ルモノナルカハ今少不明二屬スレドモ，元々 ぐりこりーせナルモノ八種々ノ理化學的影響ニョyテ左右セラルモノナルガ故 二, 今培莨温度ガぐりこーりせ二及ボス影響ヨ檢スルハ代謝學上興味ナル事項 ナリト信ズ.

\section{第 1 章赛 驗 方 法}

家鶟胎兒心臟組織 7 Carrel Fischer 八培食法ニ從ツテ之 シ，逐日的二其培食基內液狀めぢうむ中ノ糖量ノ消長 7 湘定スルト同時二培飬

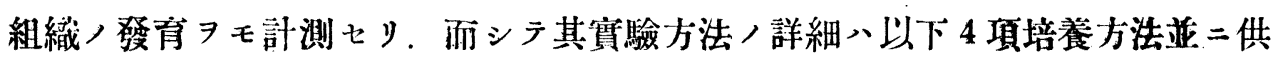

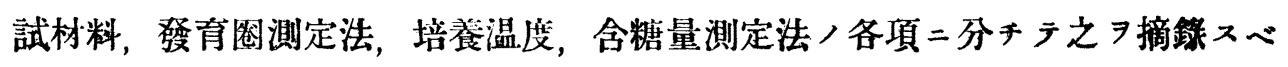
シ.

\section{第 1 節培養方法並二供試材料}

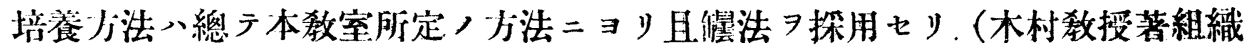
培食之研究 (術式及現况) 7 參照 ${ }_{(6)}$ ) 蓋シ本實驗八培養基內液状めぢうむ中，糖 ヨ微量测定法ニョyテ测定スルモノナレバ，各培養愳二注加スル各材料ノ分量 
八特ニ正磪ヨ期スベキモノナリ。余ハ次ノ如キ割合二注加セリ。

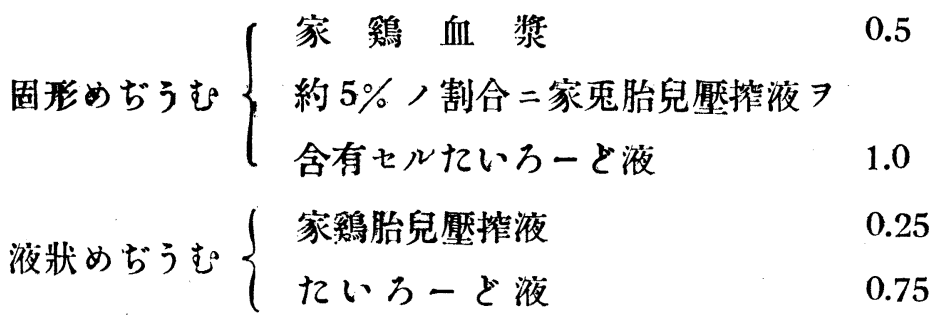

供試材料殊二血浆ハナルバク幼弱ナル家鹦ヨリ無菌的二探集セルモノニシ

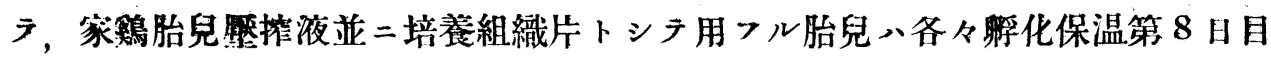
ノモノヨ撰ビ使用セリ。而シテ培食二使用セル組織片ハ何レモ大サホゾ一定二 細切シ凡ソ $0.1 \mathrm{~mm}$ トナシ, 各培養旅 $=5$ 個宛加へタリ.

\section{第 2 箅 培爰組織發有圈測定方法}

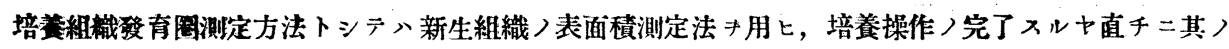
容器キVertikaler Projektionsapparat 二每常りノ擴大力キ一定二装置シテ投影せル培養組織ノ外型キ描 察盤上二周定セル紙面二描寫シ置キ，次二培養穓キ保温シ所要時間每二再ビ同一裝置ノ下二發青面ノ外

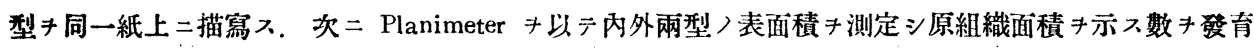
圈面皘ヨリ减シタル數ハ培養ノ絕體成長價キ表ハシ，此絕體成長價キ原組織片ノ面積キ表ハフ數二テ除

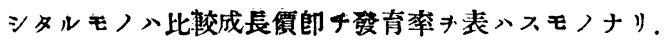

\section{第 3 節 培 養温度}

本實驗ハ温度ノ變換ニョル組織ノぐりこりーぜ觀察スルモノナルガ故二, 之ヨ撰ビタル温度八通常培食二用フル温度ヨ中心トシテ，左ノ 3 培養温度郎チ $37 \mathrm{C}, 40^{\circ} \mathrm{C}, 43 \mathrm{C}$ ᄏ適用セり.

\section{第 4 節 含糖 量 測定 法}

含糖量测定法八實驗材料ガ比較的少量ナルタメ，其測定、微量測定法トシテ 正確ナル值ヨ與フル彼ノHayedorn-Jensen (10) 氏法ニョリタリ.

\section{第 2 章實 驗成樍}

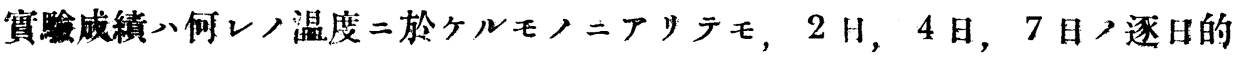




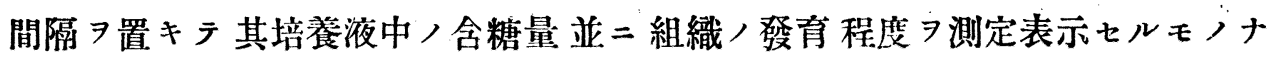
リ.

元々其等ノ檢索ハ總ラ同一培養瓶ニ就テ日ヨ逐フラ檢查スルハ至當ナレド モ，同一唒二於テハ被檢液僅少ニシテ數回ノ檢查二堪へズ且雜菌ノ污染 スル恐レアルョ以テ，檢查八總テ同一要件ニテ培養セラレタル別個ノ培養瓶各 3 個二就テ，經日的二其含㜍量並二組織, 發育度 7 測定七り。郎チ培養所定時 間ノ組織ノ發育、各 3 個ノ培養瓶內組織, 發育菜ノ本均價 $尹$ 以テ表ハシ, 含糖 量ノ表示ハ罍該 3 個ノ培養瓶內液状めぢうむヨ全部集メンノ一定量二就テ反覆 試驗

\section{第 1 節 豫 備 試 驗}

先ヅ實驗ノ對照トシラ組織习附加セザル培養基が實驗ニ撰用セル温度ニョリ 其培養基中，含糖量二影響スルコトナキカヨ檢センガタメ，實驗瓶卜同條件， 元二之 $737^{\circ} \mathrm{C}, 40^{\circ} \mathrm{C}, 43^{\circ} \mathrm{C}$ /瞬卵器ニヨサタ日 日逐フラ取り出シ其含糖量 檢セり.

第 1 表 組織片 附加セザル培養基 $737^{\circ} \mathrm{C}=$ 保温セル境合

\begin{tabular}{|c|c|c|c|}
\hline $\begin{array}{c}\text { 培養基內起始糖量 } \\
(\%)\end{array}$ & $\begin{array}{c}\text { 培養第 } 2 \text { 日貝) 含糖量 } \\
\text { (\%) }\end{array}$ & $\begin{array}{c}\text { 培養第 } 4 \text { 旦) 合糖量 } \\
\text { (\%) }\end{array}$ & $\begin{array}{c}\text { 培養第 } 7 \text { 日貝) 含糖量 } \\
\text { (\%) }\end{array}$ \\
\hline 0.141 & 0.141 & 0.141 & 0.141 \\
\hline
\end{tabular}

第 2 表 組織片 $习$ 附加セザル培養基 $740^{\circ} \mathrm{C}=$ 保温セル㙋合

\begin{tabular}{|c|c|c|c|}
\hline $\begin{array}{c}\text { 培養基內起始糖量 } \\
\end{array}$ & $\begin{array}{c}\text { 培養第 } 2 \text { 日貝) 含糖量 } \\
(\%)\end{array}$ & $\begin{array}{c}\text { 培養第 } 4 \text { 旦) 貝) } \\
\text { (\%) }\end{array}$ & $\begin{array}{c}\text { 培養第 } 7 \text { 日貝) 含糖量 } \\
(\%)\end{array}$ \\
\hline 0.141 & 0.142 & 0.140 & 0.141 \\
\hline
\end{tabular}

第 3 表 組織片 附加セザル培養基 $743^{\circ} \mathrm{C}=$ =保温セル塲合

\begin{tabular}{|c|c|c|c|}
\hline $\begin{array}{c}\text { 培養基內起始糖量 } \\
\end{array}$ & $\begin{array}{c}\text { 培養第2 }(\text { 目) 含糖量 } \\
\end{array}$ & $\begin{array}{c}\text { 培養第 } 4 \text { 旦貝) 含糖量 } \\
\text { (\%) }\end{array}$ & $\begin{array}{c}\text { 培養第 } 7 \text { 日貝) 含糖量 } \\
\text {. } \% \text { ) }\end{array}$ \\
\hline 0.141 & 0.140 & 0.141 & 0.141 \\
\hline
\end{tabular}

以上 3 表ノ示スガ如ク何レノ培養温度 


$$
\text { 本井䫓三 遮 }
$$

培食經過中何レモ起始糖量ト大差习認ムルコトヨ得ズ.

之ニョリテ培養基二組織片 $习$ 附加セザル時ハ, 之二何レノ温度 ルモ解糖現象ヨ起サザルコトヨ知リ得べシ.

\section{第 2 節本試驗}

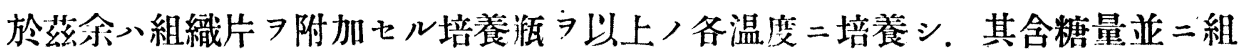
絵ノ發育度

第 4 表 $37^{\circ} \mathrm{C}$ 培養二於ケル組織,發育率

\begin{tabular}{|c|c|c|c|}
\hline 培養瓶番號 & $\begin{array}{c}\text { 培養第 } 2 \text { 日 } \\
\text { 組織 } / \text { 比較成長償 }\end{array}$ & $\begin{array}{c}\text { 培養第 } 4 \text { 日 } \\
\text { 粗織/比酸成長價 }\end{array}$ & $\begin{array}{c}\text { 培養第 } 7 \text { 日 } \\
\text { 組織 } \\
\text { 比此成長價 }\end{array}$ \\
\hline 1 & 7.5 & 42.3 & 65.2 \\
\hline 2 & 7.3 & 43.1 & 66.0 \\
\hline 3 & 7.2 & 35.4 & 69.5 \\
\hline 本均 & 7.4 & 40.3 & 66.8 \\
\hline
\end{tabular}

第 5 表 $37^{\circ} \mathrm{C}$ 培養ニ於ヶル培養基内含糖量

\begin{tabular}{|c|c|c|c|c|c|}
\hline & & 養 起 始 & 培養第 2 日 & 培養第 4 日 & 培養第 7 日 \\
\hline $\begin{array}{c}\text { 培養基內合糖量 } \\
(\%)\end{array}$ & & 0.141 & 0.131 & 0.125 & 0.103 \\
\hline
\end{tabular}

第 6 表 $40^{\circ} \mathrm{C}$ 培善二於ヶル組織發育荃

\begin{tabular}{|c|c|c|c|}
\hline 養瓶番號 & $\begin{array}{c}\text { 培養第 } 2 \text { 日ノ } \\
\text { 組織ノ比较成長價 }\end{array}$ & $\begin{array}{c}\text { 培養第 } 4 \text { 日 } \\
\text { 組織 } \\
\text { 比校成長價 }\end{array}$ & $\begin{array}{c}\text { 培養第 } 7 \text { 日 } \\
\text { 組織 / 比較成長價 }\end{array}$ \\
\hline 1 & 18.4 & 62.1 & 71.1 \\
\hline 2 & 23.1 & 62.4 & 66.0 \\
\hline 3 & 20.6 & 64.3 & 77.5 \\
\hline 本均 & 20.4 & 62.9 & 71.2 \\
\hline
\end{tabular}


第 7 表 $40^{\circ} \mathrm{C}$ 培養ニ於ケル培食基內含糖量

\begin{tabular}{l|c|c|c|c}
\hline & 養 起 始 培 & 養培第 2 日 & 培養第 4 日 & 培食 第 7 日 \\
\hline $\begin{array}{c}\text { 培食基內含糖量 } \\
(\%)\end{array}$ & 0.141 & 0.129 & 0.115 & 0.090
\end{tabular}

第 8 表 $43^{\circ} \mathrm{C}$ 培養ニ於ヶル組織, 發育荃

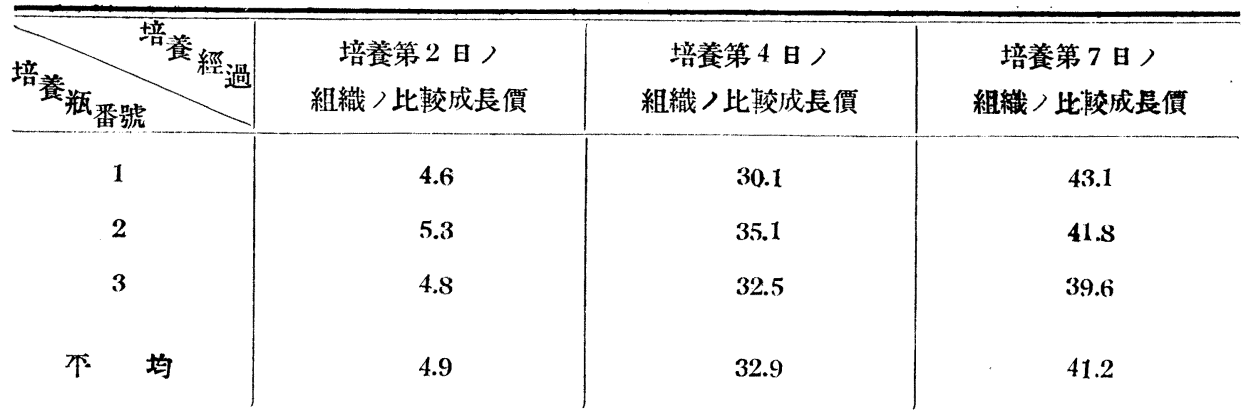

第 9 表 $43 \mathrm{C}$ 培食ニ於ヶル培基基内含糖量

\begin{tabular}{|c|c|c|c|c|}
\hline & 培養 起 始 & 培養第 2 日 & 培養第 4 日 & 培養第 7 日 \\
\hline $\begin{array}{c}\text { 培養基内含糖量 } \\
\text { (\%) }\end{array}$ & 0.141 & 0.134 & 0.129 & 0.112 \\
\hline
\end{tabular}

以上諸表ノ示ス如ク各温度ニ於ヶル含糖量ノ戀化ハ，各瓶何レモ培䓹ノ經過 卜共二逐月的二其糖量ハ减少スルタ見ル。

就中 $40 \mathrm{C}$ 培養ノモノニアリテハ其减少率最モ著明ニシテ，培食第 2 日 0.129

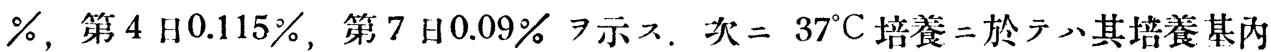
含䅯量八培食第 2 日 $>0.13 \%$ ，第 4 日 $0.125 \%$ ，第 7 日 $0.103 \%$ ニシテ，其糖消 費䇣、 $40 \mathrm{C}$ 培養,ンレニ次グ.

$43 \mathrm{C}$ 培䓹ノモノ八3 温度ノ中最モ解糖作用弱ク，第 7 日目二於テ其培餋基 內糖量漸ク $0.112 \%$ ヨ示七リ。

以上ノ事實ニヨリテ解㜍現象ノ培飬温度ニョリテ變化スルコトハ明カ二首肯 シ得ラル．郎チ組織ノ解糖作用、 $40 \mathrm{C}$ 二於テ最モ强ク $37^{\circ} \mathrm{C}$ 之二次ギ $43^{\circ} \mathrm{C}$ 最モ弱キヨ知ルベシ.

一方組織,發育 $\ni$ 見ルニ其發育度 $40 \mathrm{C}$ 培飧ノモノモ最モ良ク $37 \mathrm{C}$ 之二次 
ギ $43^{\circ} \mathrm{C}$ 最モ弱シ。郎チ $40^{\circ} \mathrm{C}$ 培養ニアリテハ培飧經過第 7 日 $=71.2$ 比較生長 價 $ᄏ$ 示ス二對シ $37^{\circ} \mathrm{C} \leadsto 66.8,45^{\circ} \mathrm{C} \leadsto 41.2$ ᄏ計上セリ。

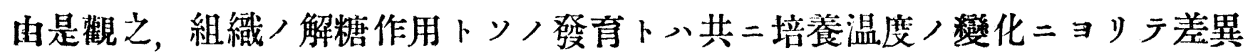

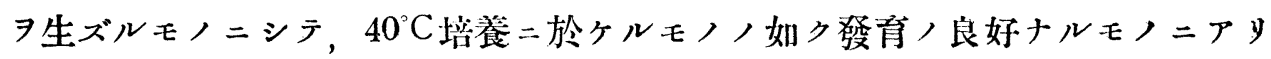
テ八解糖作用モ亦盛ンニシテ， $43^{\circ} \mathrm{C}$ ，如ク發育惡キテモノニテハ解糖作用亦劣 弱ナルコトヨ知ルベシ.

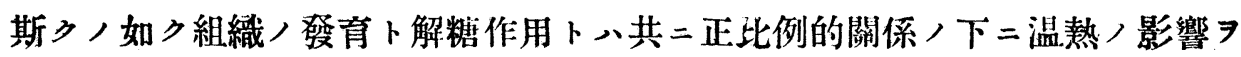
被ムル。此關係八余ガ噮二温度，乳酸產生二及ボス影響 知y得タル乳酸產生卜發育卜ノ關係二相一致スルモノニシテ, 此等, :ッノ事 實 7 綜合スル侍二益々解糖作用並二乳酸産生ガ組織ノ發育二密接ナル關係二ア ルタ思ハシム。

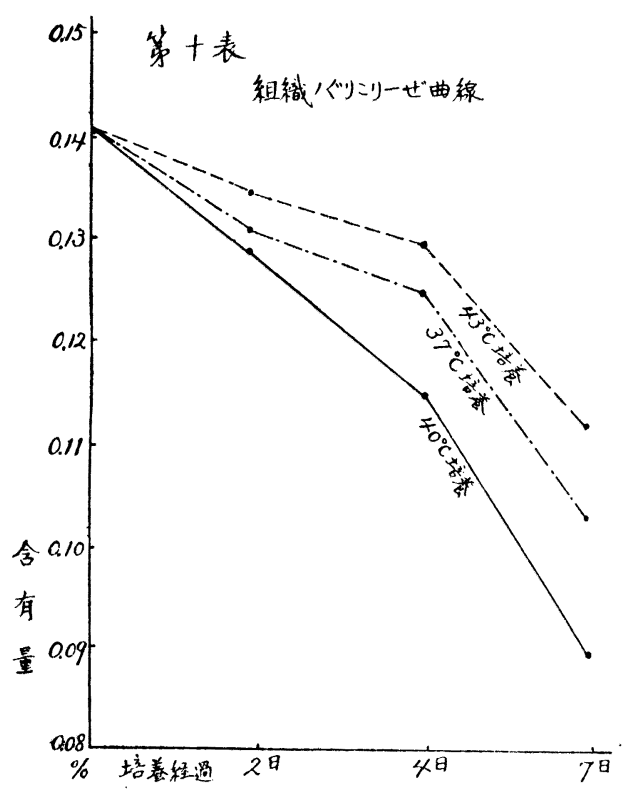

第 3 章稳

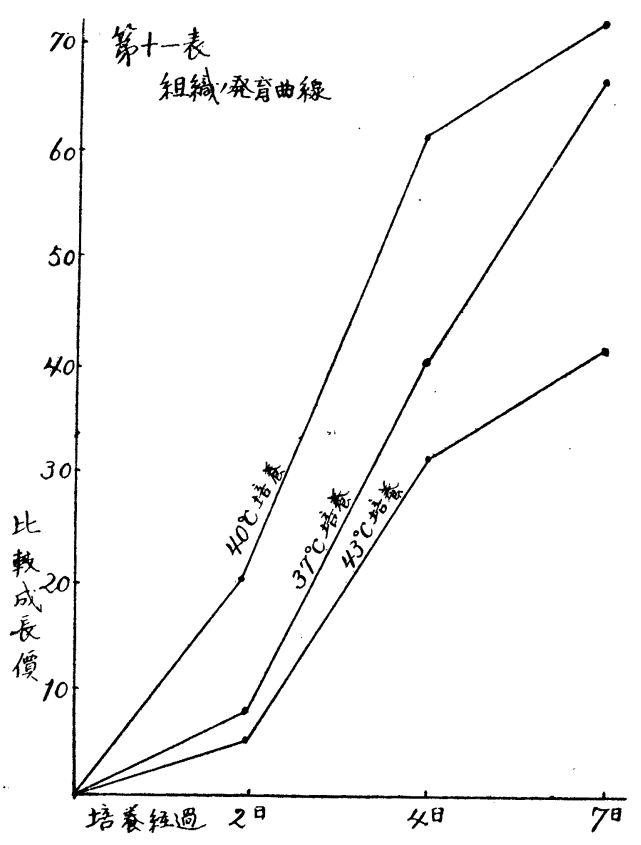

综

余》培養温度ノ戀化ガ組織くぐりこリりぜニ及ボス影響习觀察セントシテ, 家鵎心臟 7 體外二培食シ, 組織, 發肖 7 見ルト共二其培食基雨糖量，變化 7 
Hagedorn jensen 氏微量測定法ニョリ測定シ，次二總括スルガ邚キ結果二到達セ リ。

（1） $40 \mathrm{C}$ 培飬二於ヶル組織ノく゚りこり一世少 $37^{\circ} \mathrm{C}$ 培食特ノソレョリモ强 ク $43^{\circ} \mathrm{C}$ /境合ョリモ遥カ二强シ.

（2）培食基内含糖量，减少率八組織，發育紮二正比例入.

之ヨ要スルニ組織ノぐりこり一せ心温度ニョリテ差異 育 $习$ 促進スル温度八其ノぐりこり一せヨモ旺盛二ス。斯ク，如ク組織ノ發育並 こぐりこり一世共二温度ニョリテ影響セラレ其間二一定ノ正比例的關係〉存 スルモノナレドモ, 此兩者ノ關係ガ果シテ何レヨ原因トシテ何レヨ結果トスル モノナルャ, 換言スレバ組織, 發育ガ良好ナルガタヌニソノ解糖作用ガ旺盛二 ナルモノナルカ, 將又組織ノ解糖作用ガ盛ナルガタメ二其發有ガ促進サル、モ ノナルカ, 今遽ニ之ヨ斷ズルニ難ケレドモ, 余ノ按ズル所恐ラク Warburg, 所謂 Ohne Glycolyse Kein Wachstum ナル說, 如ク, 組織, Glycolytische Ferment ガーニハ温熱作用ニョリテ Activieren セラレ, 解糖作用ヨ惹起シ, 其際發生スル化學的えねるぎーガ組織發育ノえねるざーニ轉化スルモノナラ ンカ.

\section{第 4 章結論}

（1）組織へりこりーぜ强度》培餋温度ニョリテ差アリ。

(2) 組織ノべりこり一せ六組織ノ發育卜正比的關係 $\ni$ 有ス.

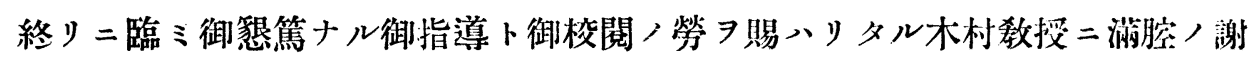
意 $尹$ 表ス。

\section{文献}

1) 平井, 日本微生物病理學雜誌, 第24卷, 第11號.

2) Warburg, Ueber den Stoffwechsel der Tumoren. Berlin, 1926.

3) Meyerhof, Pflüger's Arch. f. gesamt. Physiol. 204, 448, 1924. 4) Krontowski u. Bronstein, Archiv f. exp. Zellforsch., 3, 32, 1927.

5) 稫光廉平, 日本微生物生理學雜誌, 第23卷, 第 10 號前 第24卷，第3號。

6）太田喜直，日本微生物病理學雜誌，第2 4 卷，第2號前同卷,第 8 號.

7) Demuth u. Meier, Bischem. Zeitscinr. 212, 399.

8) Roffo, Zentralbl.

f. Bact. Ref. 96, 114, 1929.

9) 木村廉, 組織境養, 研究 (術式及現况) 昭和5年4月.

10) Hagedorn Jensen, Bischem. Zeitschr. Bd. 135, S. 46, 1923. 